\title{
A THEOLOGICAL SUPPORT, FROM CHALCEDON, TO THE SHROUD IMAGE NATURAL FORMATION
}

\author{
Prof. PhD. Giovanni FAZIO, \\ Università di Messina, Dipartimento MIFT \\ Viale Ferdinando Stagno d'Alcontres, I-98166 Messina \\ ITALY \\ E-mail: gfazio@unime.it,
}

\begin{abstract}
The fourth Ecumenical Council of Chalcedon (451 AD) sanctions, for the Holy Church very important conclusions regarding the nature of Christ. The above results do not contrast, but rather open to a natural formation of the Shroud body image. This occurs because it was affirmed in Chalcedon that Jesus Christ, the Nazarene, has two natures, one human and one divine, "inconfusedly, unchangeably, indivisibly, inseparably", which coexist in one person (hypostasis). Consequently, the monophysitism of Eutiche and of the Egyptian, Syrian and Armenian Churches, was rejected. Now, the Resurrection of the Nazarene is a Transcendental event that, according to those like us who support the natural formation of the Shroud body image, acted only on the corpse leaving the burial linen in the Immanent, under the dominion of the natural sciences. So, the Miracle of the Resurrection shows the divine nature of Christ, while the Shroud body image formation, the human one.
\end{abstract}

Keywords: Shroud body image; natural formation; Council of Chalcedon; monophysitism; dyophysitism; hypostasis;

\section{INTRODUCTION}

Nowadays, there are many archaeological findings that have not had a clear explanation. Among these the Linen of Turin deserves an important place, studied for over a century by both scientists and people. The former ones, despite their historical, technical and scientific knowledge furnish different results that we crudely list: for some the above burial linen cloth is a fake, for others it is the result of a Miracle due to the Omnipotent, for still others (a minority of scientists) it is due to a natural process. However, the majority of the scientists are divided between the ones that support the Transcendental event and others that believe in the action of a Medieval forger.

With this state of affairs, the Shroud's world becomes a very confusing research area (Fazio 2016). Moreover, it is opportune to take into account that religion has a weight in this scientific research. Obviously, its action is bidirectional: believers go in their well precise direction (the sheet is the burial one of the Nazarene) while atheists, anticlericals and agnostics in the opposite one (the sheet was produced by a Medieval forger). Thus, the results of the former are rejected by the latter and vice versa.

The goal of the research on the Linen of Turin is to understand the mechanism of the body image formation. A process sought with determination for over a hundred years and never fully understood. 
Moreover, an important problem is also understanding who the man of the Shroud is. Our unchangeable conviction is that such a man can only be Jesus Christ, the man of Nazareth. This certainty is due to the distribution of blood on the sheet in relation to the body image, to the evident correspondences between the Turin Shroud and the Sacred Texts and other Messianic prophecies present in the aforesaid Texts (New American Bible 2010).

a. The characteristics of the blood image. The center of each stain shows the presence of both hemoglobin and albumin, the corpuscular part of the blood (Heller and Adler 1981; Schwalbe and Rogers 1982, Pellicori 1980). All around the bloodstains, there is the serum, perfectly visible in fluorescence (Miller and Pellicori 1981). Such stains are of body-sheet contact: the Shroud wrapped a wounded human body by flagellation and crucifixion (Bucklin 1982, Zugibe 2005).

b. The presence of bile pigments (Heller and Adler 1981) in such a quantity as to explain the unspeakable suffering endured by the Nazarene during His Passion.

c. The perfect correspondence among the wounds described in the Sacred Texts (New American Bible 2010) and the blood image as it appears in the Linen of Turin (Bucklin 1982, Zugibe 2005)

d. On the linen there are wounds which have nothing to do with Roman crucifixion. They are to the forehead, nape and chest and are clearly described in the four Gospels (New American Bible 2010).

e. The bones of the Crucified, during His Passion were not broken, as it is written in the Old (Psalms 34, 20) and New (John 19, 33-36) Testaments (New American Bible 2010).

f. The other Messianic prophecies. As an example, we can cite (Isaiah 50, 6; 53, 5; 53, 7) and (Psalms 22, 7; 22, 16).

g. The face of the Man who has suffered so much violence is devoid of the "grin"; the typical smile that appears evident in people who have died brutally. On the contrary, our Man shows a great serenity.

\section{MECHANISMS OF IMAGE FORMATION}

We neither believe the fake hypothesis nor the miraculous one. The first one is discarded due to the results obtained by the STURP team (STURP'S Conclusion 1981, Jumper et al. 1984) which, among other things, affirms: "The data, taken together, do not support the hypothesis that the images on the Shroud are due to an artist." Moreover, in addition to considering the items from a) to g), we must take into account that the formation of the blood image has preceded that of the body image. This is what a Medieval artist/forger would have done.

The distribution of yellowed fibrils lies in the region of the body image and are mixed with the background color. All these fibrils, which tick 10-15 micron each, have the same optical density value (Pellicori and Evans 1981) regardless of the $\mathrm{z}$ body-burial linen distance (with $\mathrm{z}$ that range from 0 to $\mathrm{R}_{0}=37 \mathrm{~mm}$ (Jackson, Jumper and Ercoline 1984)) and the body image that 'floats' in the linen since its thickness is 20-30 micron only (Mottern et al. 1980). In addition, the linen of our concern has such complex characteristics even for a skilled medieval forger.

The second one is widely described and discussed in literature by many authors. However, because of the various ways it is presented, it is theologically inconsistent (Fazio 2020). These scientists should know that the Transcendental events are incomprehensible for the natural sciences and, obviously, for the people. Miracles are due to God and only to Him. 
Therefore, they happen instantly (see Lourdes (De Franciscis and Anastasi 2021)). Consequently, the natural sciences can only affirm that such an event has occurred. In fact, they cannot be described step by step, as occurs during a natural event that is under the dominion of natural science. Thus, all the papers present in literature describing a Miracle to explain the Shroud body image formation must be rejected.

Obviously, we cannot exclude the Miracle due to the Omnipotent. However, a mathematical correlation, for this image on the Linen of Turin, exists between the density of yellowed fibrils (those that highlight the body image) and the body-sheet distance (Jackson, Jumper and Ercoline 1984). This suggests a natural process in the formation of the Shroud body image (Fazio, Mandaglio and Anastasi 2019). This last hypothesis is also supported by the "Ockham's razor" that is often considered in the scientific world (Soklakov 2002).

We recall that the "Ockham's razor" is not a physical law. However, in the case of several hypotheses that need to be considered for an explanation, it suggests that the most probable is the one that requires the least number of special assumptions. In these cases, we have the highest probability of being closest to the truth. William of Ockham was a Franciscan friar, theologian and philosopher, known supporter of the separation of the Temporal and Spiritual powers. He lived between the thirteenth and fourteenth centuries.

\section{BURIAL, RESURRECTION, LATENT IMAGE}

Our analysis begins when the corpse of the Nazarene was taken by Joseph of Arimathea and Nicodemus. The two men, both with the women and John the evangelist, went to the Sepulcher and after sprinkling the body with balms and ointments, according to the Jewish burial custom, placed The Lord on the tombstone (The New American Bible 2010). Here, due to the difference between the thermal states of corpse and sheet, there was a transfer of thermal energy (the only, reasonably, present in a first century tomb) from the corpse to the sheet. Also, if the quantity transferred is very little, the Nazarene distributed energy to the burial linen (the sowing soil) preparing the conditions for developing the latent self-image, resulting from the action of the stochastic process triggered by the small amount of energy (Fazio et al. 2015).

At the instant of the Resurrection, with the disappearance of Jesus Christ, the burial linen remained flattened on the stone in the Sepulcher. Consequently, the above linen did not receive the nitrogen compounds (like ammonia, amines and diamines) which are emitted by the corpses during their decompositions. These chemicals would have destroyed any image or any trace of it. This clarifies the uniqueness of the Shroud body image. For all other corpses the burial sheets receive the chemical products leaving sheets entirely stained.

However, the Resurrection left the burial linen without the wrapped body of Jesus Christ. The sheet remained in the region of the Immanent (practically, under dominion of natural sciences). The energy already distributed is sufficient to trigger the natural process. In fact, only with zero transferred energy, the stochastic effects are absent. On the contrary, when there is a transfer, the effects are present but are latent. Thus, this explains why the evangelists did not write about an imprinted image of the Nazarene on the burial linen. The body image will appear after years or decades. In fact, as we have already written, the effects of a stochastic process are latent (Fazio et al. 2015). These two events, Resurrection and Shroud body image formation, remind us that Jesus Christ is truly God and truly man. The first one is a Transcendent event (Miracle), the second one is in line with the laws of the natural sciences (Fazio, Mandaglio and Anastasi 2019) because the image formation is a natural process as the ones that occur in the Immanent. 


\section{International Journal of Theology, Philosophy and Science \\ No. 8, Year $5 / 2021$ \\ https://ijtps.com/ \\ ISSN 2601-1697, ISSN-L 2601-1689}

\section{THE 451 AD COUNCIL OF CHALCEDON}

Now, to understand the nature or natures of Jesus Christ, we shall go back in time, sixteen centuries ago, to review the conclusions of the fourth Ecumenical Council of Chalcedon. At that time, the Greek Eutiche, theologian and Archimandrite of a large monastery in the area of Constantinople, was the main guide of the monophysitism (Acerbi 2006) which supports the hypothesis that the person of Jesus Christ has only the divine nature. The monophysists were present in the Egyptian, Syrian and Armenian Churches. On the contrary, the Eastern Orthodox Church, the Roman Catholic Church and the Eastern Catholic Churches, the Anglican Church, the Old Catholic Church and various other little Christian Churches, were the proponents of the dyophysitism that accepted and supported the two natures, both divine and human, of Jesus Christ.

The Mysteries of the Christology (O'Collins 1995, Xavier 1996, Kessler 2010) were already debated since the first centuries (and are still today). However, at the beginning of the fifth century the double nature of Christ was so debated that a schism could have been close. With this state of affairs, the fourth Ecumenical Council of Chalcedon, ancient city of Bithynia (Asia Minor), was convened by the Eastern Roman Emperor Marciano. The Council was celebrated in the Basilica of S. Euphemia where the participating Bishops were several hundred. There, during the month of October, these Christological themes were widely debated with many interventions, discussions and comparisons.

Finally, it was the first of November 451 AD, the majority of the Council established that: i) the monophysitism of Eutiche, supported by the Churches of Egypt, Syria and Armenia, was condemned, ii) Jesus Christ of Nazareth is fully God and fully man. He has two natures, a human and a divine one, "inconfusedly, unchangeably, indivisibly, inseparably" which coexist (hypostasis) in one person. Here, it is opportune to recall the Gospel of (John 1,1): "In the beginning was the Word, and the Word was with God, and the Word was God (The New American Bible 2010). Here, we remind the reader of the Encyclical Letter of Pio XII about the fourth Ecumenical Council of Chalcedon which took place in the fifth century (Pio XII 1951). However, this Ecumenical Council with its dogmatic definition did not cease the controversy about the nature or natures of Jesus Christ.

To this point, remembering that the pillars of the Christian Creed are Revelation and Tradition, we should make some considerations. In fact, what is discussed in this article can be considered an example of how Tradition works. However, we affirm: Tradition is not less important than Revelation. Among other things, at the beginning, when the Gospels were not written, for at least three decades, Tradition had supported the commitment to expand the Belief. Thus, the hypothesis of the formation of the Shroud body image, by natural process, is not against the conclusions of the fourth Ecumenical Council of Chalcedon. In the sense that the image of the Nazarene, that appears on the Shroud, may have formed naturally representing the human nature of Jesus Christ. This result, beyond our scientific (Fazio, Mandaglio and Anastasi 2019) and religious (Fazio 2020) convictions and conclusions, is unexpected and by us highly appreciated. The Resurrection of the Nazarene is a Miracle, while our hypothesis of the Shroud body image formation is an event that lies in the Immanent, where everything is governed by the natural sciences.

After this analysis, we can affirm what happened about XX centuries ago: "The Resurrection of the Nazarene was a Transcendental event that did not act on the burial linen." This remained on the stone in the sepulcher and from there, after a dozen centuries, reached Europe. Currently, it is in the Guarini's Chapel. In any case, a definitive comprehension of the body image formation is increasingly linked to the presence of a natural process. 


\section{CONCLUSION}

We are sure that, for the Turin Shroud, the false hypothesis, as the miraculous event, is not adequate for the understanding of the formation of the body image. Consequently, only a natural process is able to obtain the desired result. In this context, we must also consider the natural hypothesis made by Rogers: a Maillard reaction between nitrogen compounds coming by the corpse's degradation and reducing sugars present on the linen threads due to the manufacturing procedure. (Rogers and Arnoldi 2002 and 2003; Rogers 2008)

Also, our natural process, the stochastic one, has been already studied (Fazio, Mandaglio and Anastasi 2019). Unfortunately, the two mechanisms have not had the attention we hoped. We are certain that this occurs because almost all scientists are for the false hypothesis or for the miraculous event. Moreover, we must also take into account the religious problems always present in the Shroud of Turin research. It seems that to be considered scholars of the Shroud of Turin, it is necessary to belong either to the ones who support the hypothesis of the Medieval forgery or to those in favour of the miraculous event. These two visions (fake and Miracle) are still in constant contrast today, generating confusion upon confusion and making the solution of the problem more difficult.

To prove our reasons, we have acted at first with the support of the natural science laws. For example, with articles (Fazio et al. 2015) where we demonstrated that the yellowed fibrils distribution is the result of the action of a natural process, the stochastic one, excluding the Transcendental event and the presence/act of a Medieval forger. Uselessly!

Thus, in this article, as we have already done previously (Fazio 2020), we also turn to Theology and Christology to reach the result. In fact, as it clearly appears in this article, the choice of this line of research has produced new interesting results. They give major consideration to the natural formation of the Shroud body image, removing the other hypotheses. 
ACKNOWLEDGEMENTS: Remembering Giovanni Sturniolo Villa, one of my dearest friends. With his behaviour, he helped me to be a Catholic Christian. The author thanks the Prof. Rosanna Callipari, for the revision and improvements of the English language.

\section{BIBLIOGRAPHY:}

[1] Acerbi, Silvia. 2006. Il potere dei monaci nei Concili Orientali del V secolo: Il Costantinopolitano Eutiche e il Siro Bar Sauma. Ediciones Universidad de Salamanca. ISSN 0213-2052: 291-313. http://catalogo.unican.es/cgi-bin/abnetopac/?TITN*343228. In Italian language

[2] “A Summary of STURP'S Conclusion." STERA Inc., Barrie M. Schwortz Director and Editor, 1981. https://www.shroud.com/78conclu.htm

[3] Bucklin, Robert. 1982. The Shroud of Turin: A Pathologist's Wiewpoint", in Legal Medicine Annual (C- Wecth Editor, Stanford University): 33-39.

[4] De Franciscis, Alessandro, and Filippo Anastasi. 2021. I misteri di Lourdes. Effata Editrice, Cantalupa, Torino. In Italian language

[5] Fazio, Giovanni, Veronica De Leo, Francesca Curciarello, and Giuseppe Mandaglio. 2015. "Comparison among the Shroud body image formation mechanisms by fibrils distributions". in Journal of The Textile Institute 106: 896-899.

[6] Fazio, Giovanni. 2016. "The scientific approach vs the open 'Linen of Turin questions' is it the right one?", in Journal of The Textile Institute 107: 1607-1609,

[7] Fazio, Giovanni, Giuseppe Mandaglio, and Antonio Anastasi. 2019."Describing, step by step, the Shroud body image formation", in Heritage 2: 34-38.

[8] Fazio, Giovanni. 2020. "The Shroud Body Image Generation. Immanent or Transcendent Action?", in Scientia et Fides 8(1): 33-42.

[9] Heller, John H., and Alan D. Adler. 1981. "A Chemical Investigation of the Shroud of Turin", in Canadian Society of Forensic Sciences Journal 14: 81-103.

[10] Jackson, John P., Eric J. Jumper, and William R. Ercoline. 1984. "Correlation of image intensity on the Turin Shroud with 3D structure of a human body shape", in Applied Optics 23: 2244-2270.

[11] Jumper, Eric J., Alan D. Adler, John P. Jackson, Samuel F. Pellicori, John H. Heller, and James R. Druzik. 1984. "A comprehensive examination of the various stain and images on the Shroud of Turin", in ACS Advance in Chemistry. Archaeological Chemistry III 205: 447-476 and references therein.

[12] Kessler, Hans. 2010. Cristologia. Editrice Queriniana. Brescia. In Italian language

[13] Miller, Vernon D., and Samuel F. Pellicori. 1981. "Ultraviolet Fluorescence Photography of the Shroud of Turin", in Journal of Biological Photography 49: 71-85.

[14] Mottern, Robert W.,J R. London, and Robert A. Morris. 1980. "Radiographic examination of the Shroud of Turin. A preliminary Report", in Material Evaluation 38: 39-44.

[15] O'Collins, Gerald. Christology: A Biblical Historical and Systematic study of Jesus, Oxford University Press, Oxford, 1995

[16]Pellicori, Samuel F. 1980. "Spectral properties of the Shroud of Turin", in Applied Optics 19: 1913-1920.

[17] Pellicori, Samuel F., and Mark S. Evans. 1981. "The Shroud of Turin through the Microscope", in Archaeology January/February 34-43.

[18] Pio XII, 1951. SEMPITERNUS REX CHRISTUS. Lettera Enciclica, XV centenario del quarto Concilio Ecumenico di Calcedonia. Roma.

[19] Rogers, Raymond N., and Anna Arnoldi. "The Scientific Method applied to the Shroud of Turin. A Review". 2002. Retrieved from https://www.shroud.com/pdfs/rogers2.pdf 1-38.

[20] Rogers, Raymond N., and Anna Arnoldi. 2003. "The Shroud of Turin: an amino-carbonyl reaction (Maillard reaction) may explain the image formation", in Melanoidins 4: 106-113. Office for Official Publications of the European Communities. Luxembourg. Ames, J.M. Editor.

[21] Rogers, Raymond N. A Chemical perspective on the Shroud of Turin. Joan Rogers \& B. M. Schwortz Editors. Florissant, Colorado, USA. 2008.

[22] Schwalbe, Larry A., and Raymond N. Rogers. 1982."Physics and Chemistry of the Shroud of Turin. A Summary of the 1978 Investigation", in Analytica Chimica Acta 135: 3-39. 
[23] Soklakov, Andrei N. 2003. "Occams Razor as a formal basis for a physical theory". Foundation of Physics Letters 15(2): 107-135.

[24] United States Conferences of Catholic Bishop. The New American Bible. Confraternity of Christian Doctrine Inc. Washington DC. 2010.

[25]Xavier, Tilliette. 1996. Il Cristo della filosofia. Prolegomi a una cristologia filosofica. Marcellinara, Brescia. In Italian language

[26]Zugibe, Frederick T. 2005. The Crucifixion of Jesus: A Forensic Inquiry. M. Evans and Co. Publishing. New York. 2005. 